\title{
Nautiloid cephalopods from the Rickard Hill facies of the Saugerties Member of the Schoharie Formation, eastern New York, USA (late Emsian, Devonian): A case study in taphonomy from glacial erratics
}

\author{
Martin A. Becker, Harry M. Maisch IV, Rebecca A. Chamberlain, \\ John A. Chamberlain Jr., Christi G. Kline, and Clint F. Mautz
}

\begin{abstract}
Glacial erratics belonging to the Rickard Hill facies (RHf) of the Saugerties Member of the Schoharie Formation (late Emsian, Devonian) occur scattered throughout the Lower Hudson Valley of New York and northern New Jersey Piedmont. These glacial erratics are most similar to facies exposed $\sim 200 \mathrm{~km}$ north in the Helderberg Mountains region of eastern New York. The RHf glacial erratics contain a concentrated assemblage of well-preserved nautiloid cephalopods dominated by large orthoconic and coiled forms. These nautiloids are exposed along bedding planes as a result of a complex sequence of physical and chemical weathering during transport within the Hudson-Champlain Lobe of the Laurentide Ice Sheet and deposition within acidic soils of regional ground moraines. Weathering also reveals taphonomic details within body chambers and phragmocones of these nautiloids that are not readily observable in outcrop exposures of the RHf. Some nautiloids display similar orientations on bedding surfaces while others contain casts and molds of invertebrates including trilobites, brachiopods, and corals that are preserved within and adjacent to body chambers and phragmocones. Comparison of glacial erratic samples to the bedrock source indicates that the large $\mathrm{RHf}$ nautiloids represent a post-mortem lag assemblage occurring in the same locality and depositional environment inhabited by the living animals. This postmortem lag deposit occurs at the boundary between third order eustatic sea level cycles Emsian 5 and Eifelian 1 and accumulated as part of a shallowing upward cycle bounded below and above by the sub-Aquetuck and sub-Edgecliff unconformities. Nautiloids and other invertebrate fauna were concentrated during multiple exhumation and reburial events where localized wave base was capable of eroding into the shallow shelf platform in this area of eastern New York.
\end{abstract}

Becker, Martin A., Maisch, Harry M., IV, Chamberlain, Rebecca A., Chamberlain, John A., Jr., Kline, Christi G., and Mautz, Clint F. 2018. Nautiloid cephalopods from the Rickard Hill facies of the Saugerties Member of the Schoharie Formation, eastern New York, USA (late Emsian, Devonian): A case study in taphonomy from glacial erratics. Palaeontologia Electronica 21.3.42A 1-22. https:// doi.org/10.26879/896

palaeo-electronica.org/content/2018/2359-rickard-hill-facies-nautiloids

Copyright: November 2018 Paleontological Society.

This is an open access article distributed under the terms of Attribution-NonCommercial-ShareAlike 4.0 International (CC BY-NC-SA

4.0), which permits users to copy and redistribute the material in any medium or format, provided it is not used for commercial purposes and the original author and source are credited, with indications if any changes are made.

creativecommons.org/licenses/by-nc-sa/4.0/ 
Martin A. Becker. Department of Environmental Science, William Paterson University, 300 Pompton Road, Wayne, New Jersey 07470, USA. beckerm2@wpunj.edu

Harry M. Maisch IV. Department of Environmental Science, William Paterson University, 300 Pompton Road, Wayne, New Jersey 07470, USA and Doctoral Program in Earth and Environmental Sciences, CUNY Graduate Center, 365 5th Avenue, New York, New York 10016, USA. hmaisch@gc.cuny.edu Rebecca A. Chamberlain. Department of Biology, College of Staten Island (CUNY), 2800 Victory Blvd, Staten Island, NY 10314, USA. rebecca.chamberlain@csi.cuny.edu

John A. Chamberlain Jr. Doctoral Programs in Earth and Environmental Sciences and Biology, CUNY Graduate Center, New York, New York 10016, USA and Department of Earth and Environmental Sciences, Brooklyn College, 2900 Bedford Avenue, Brooklyn, New York 11210, USA. johnc@brooklyn.cuny.edu Christi G. Kline. Department of Environmental Science, William Paterson University, 300 Pompton Road, Wayne, New Jersey 07470, USA. klinec1@student.wpunj.edu Clint F. Mautz. Department of Environmental Science, William Paterson University, 300 Pompton Road, Wayne, New Jersey 07470, USA. mautzc@student.wpunj.edu

Keywords: Rickard Hill facies; late Emsian; glacial erratics; nautiloid taphonomy

Submission: 31 May 2018 Acceptance: 12 November 2018

\section{INTRODUCTION}

In North America, some of the earliest reports of nautiloid cephalopods from the Helderberg Mountains region of New York were authored by the pre-eminent American paleontologist James Hall (Hall, 1861, 1867, 1879). As identified in these reports, one of the most abundant and diverse nautiloid assemblages in this area derives from a single Lower Devonian lithology with limited outcrop exposure within the Schoharie Formation (Grit) and specifically Albany and Schoharie Counties. From this area, a total of 43 orthoconic and coiled nautiloid species were tabulated by Grabau (1906), who also indicated that 39 of these species do not occur in higher stratigraphic horizons. Equally impressive is the fact that some of the orthoconic nautiloid species featured in Hall (1879) achieved lengths up to $60 \mathrm{~cm}$ as compared to other Paleozoic nautiloids in New York State, although none of the specimens were deemed to be complete (See: Linsley, 1994). Since that time, numerous researchers have identified and described nautiloid cephalopods from the Schoharie Formation of New York with little consensus on the total number of species (e.g., Flower, 1945; 1949; Flower and Kummel, 1950; Oliver, 1954; Johnsen and Southard, 1962; Sweet, 1964; Linsley, 1994; Brembs et al., 2015). However, none of these researchers have addressed the taphonomic conditions that resulted in the great abundance, large size, and high diversity of orthoconic and coiled nautiloids within the
Schoharie Formation, and species are either illustrated or figured as isolated specimens.

Recently, an assemblage of fossiliferous glacial erratics containing concentrations of large nautiloids were discovered scattered across the Lower Hudson Valley of New York and northern New Jersey Piedmont (Becker and Bartholomew, 2013; Becker et al., 2017). The source provenance of these glacial erratics was identified as the Rickard Hill facies (RHf) of the Saugerties Member of the Schoharie Formation and the same outcrop belt featured in the aforementioned nautiloid studies (Figure 1). During transport within the HudsonChamplain Lobe of the Laurentide Ice Sheet, a combination of physical and chemical weathering, and deposition within the acidic soils of regional ground moraines, has revealed taphonomic details of these nautiloids that are not normally seen in outcrops of the Schoharie Formation. This RHf nautiloid assemblage includes brachiopods, corals, and trilobites preserved within and adjacent to the body chambers and phragmocones of orthoconic and coiled nautiloids. Some of the RHf glacial erratics also contain orthoconic nautiloids with similar orientations along bedding surfaces and body chambers and phragmocones that are crushed, faulted, and bioeroded. These taphonomic features as observed in RHf glacial erratics provide details in the outcrop source region regarding the concentration of nautiloids within a localized depositional environment by storm events and sea level cyclicity. 


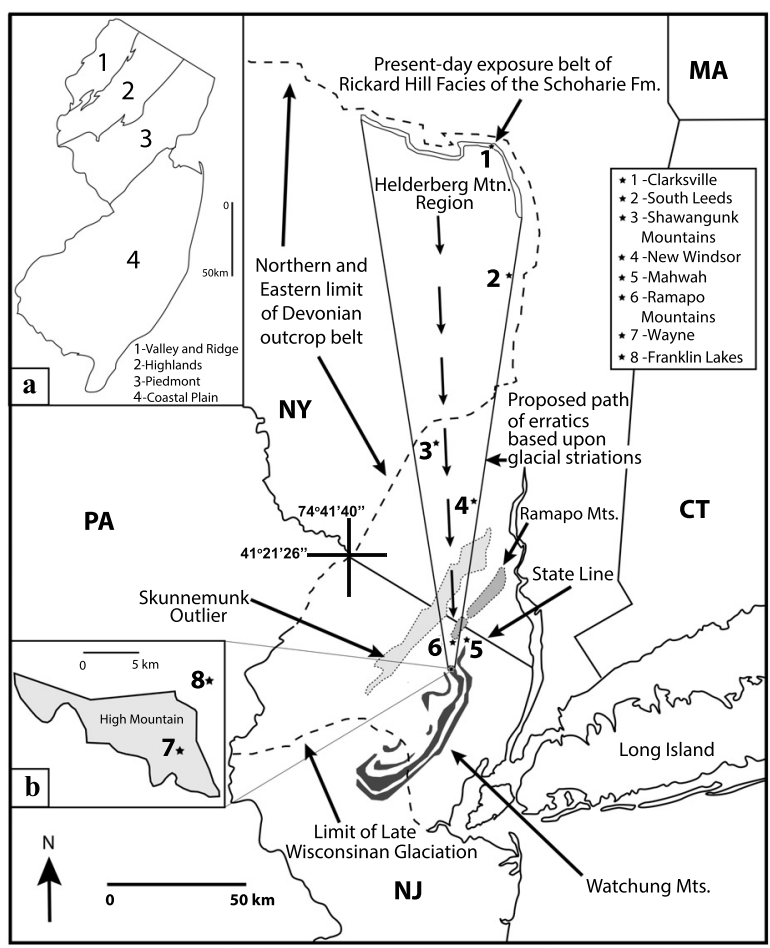

FIGURE 1. Locality map within the Lower Hudson Valley of New York and northern New Jersey Piedmont with proposed path of glacial transport from the Rickard Hill facies (RHf) of the Saugerties Member of the Schoharie Formation, Helderberg Mountains region, New York. (*1) RHf exposure belt; ( $\left.{ }^{*} 2-{ }^{*} 8\right)$ fossiliferous glacial erratics described in Becker and Bartholomew (2013); Becker et al. (2016; 2017) and this report. Inset maps: (a) physiographic provinces of New Jersey and (b) High Mountain, Wayne, New Jersey, region. Note: limit of Wisconsin Glaciation, Skunnemunk Mountains, Ramapo Mountains. Redrawn from Becker et al. (2017).

\section{SOURCE AND RECOVERY REGIONS OF RICKARD HILL FACIES (RHF) FOSSILIFEROUS GLACIAL ERRATICS}

\section{Outcrop Exposures}

The source region for the $\mathrm{RHf}$ glacial erratics containing the nautiloids described in this report is a narrow and discontinuous outcrop centered near Clarksville, New York, and the Helderberg Mountains region (Johnsen and Southard, 1962; Becker and Bartholomew, 2013); (Figures 2-3). Johnsen and Southard (1962) indicated that the abundance and concentration of nautiloids and other invertebrates that occur within the uppermost Schoharie Formation are unique in this region. It is also significant that this abundance and concentration of invertebrate fossils, specifically large orthoconic nautiloids have not been documented elsewhere within the Schoharie Formation outcrop belt that extends $300 \mathrm{~km}$ across eastern New York, northwestern New Jersey, and eastern Pennsylvania (Johnsen and Southard, 1962; Becker et al., 2017).

In Clarksville, New York, numerous thrust faults within the region surrounding the RHf have produced extensive jointing within outcrop and can also be seen within local cave systems (Cooper and Mylroie, 2015); (Figures 2-3). Along Route 85 in Clarksville, an excellent outcrop of the $\mathrm{RHf}$ occurs along with the Gumaer Island, Aquetuck, and Saugerties Members of the Schoharie Formation. Member assignments, lithology descriptions, measured sections, and sequence stratigraphy for this outcrop originally appeared in Ver Straeten (1995). A thrust fault also occurs in this outcrop that offsets these three members of the Schoharie Formation and results in drag folding of the $\mathrm{RHf}$ as seen in Figure 2.1, 2.4. We interpret regional thrust faulting such as that seen in the Route 85 outcrop to have assisted glacial plucking of the $\mathrm{RHf}$ and accelerated physical and chemical erosion of the $\mathrm{RHf}$ glacial erratics during transport within the Hudson-Champlain Lobe of the Laurentide Ice Sheet. Other outcrop exposures of the RHf such as those seen near the town of Feura Bush, New York, also share similar faulting and jointing features (Figure $3)$.

Individual beds of the $\mathrm{RHf}$ consist of dense, sandy limestone that range in thickness from a few centimeters to approximately $1 \mathrm{~m}$ and are bounded by distinct erosional surfaces as seen in Clarksville and Feura Bush (Figures 2.5; 3.1). Bedrock weathers yellowish-brown to tan across exposed surfaces and as a thin rind typically less than a few centimeters thick, while freshly broken and unweathered interior surfaces are grayish-blue and occasionally contain pyrite (Figure 2.5). Fossil concentrations of nautiloids in RHf outcrops can be observed infrequently along some bedding planes and in cross-section as casts and molds. However, the bedrock typically obscures many anatomic and taphonomic details such as suture patterns, shell ornamentation, or conchs that display similar orientations (Figures 2.3-5; 3.2).

\section{Glacial Erratics}

In the Lower Hudson Valley of New York and northern New Jersey Piedmont, RHf glacial erratics containing nautiloids were recovered from ground moraines with specific locations identified in Figure 1. Glacial erratics belonging to the RHf are uncommon in these areas and occur scattered with other 


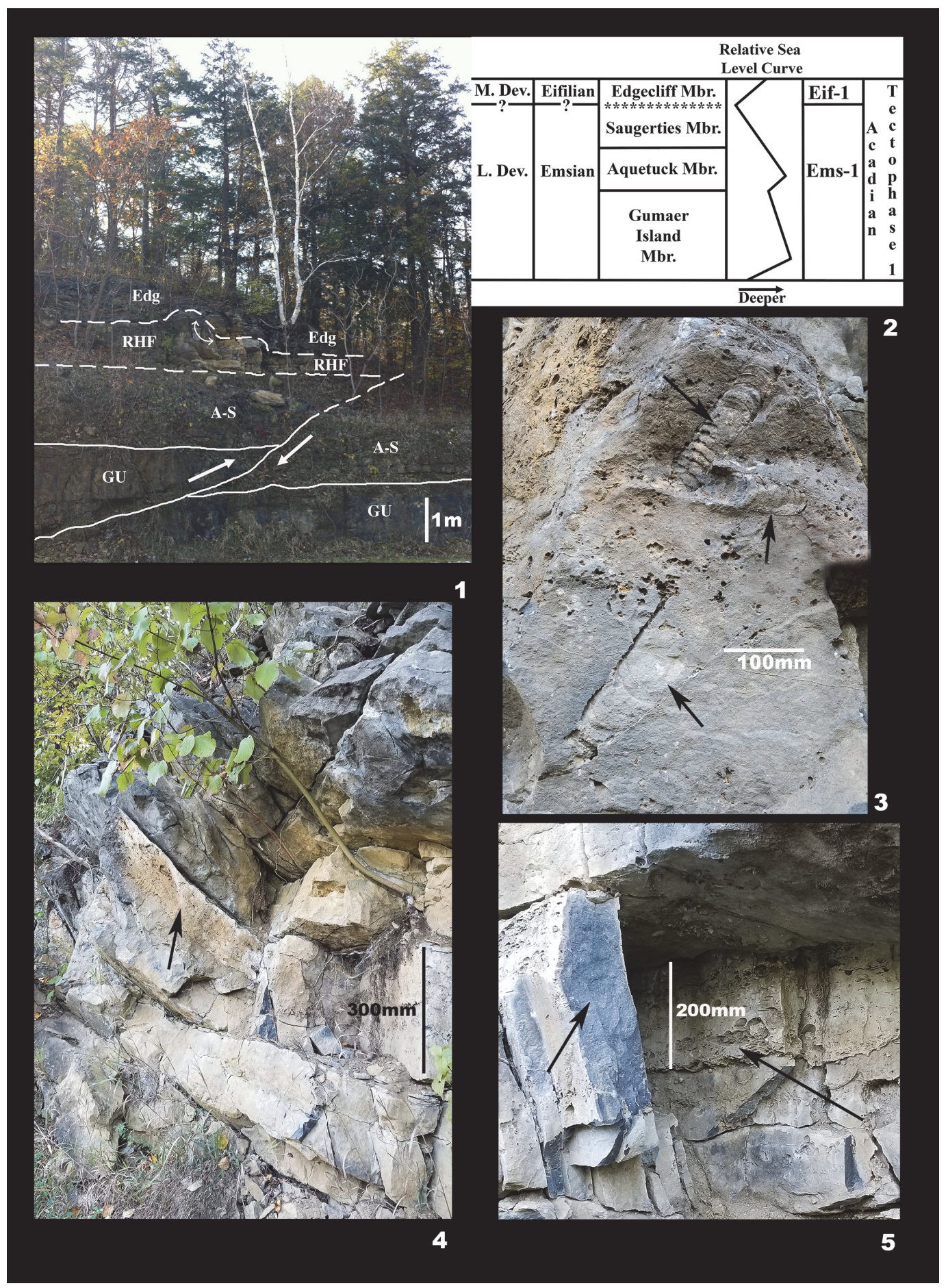

FIGURE 2. Outcrop exposure of the RHf with Gumaer Island, Aquetuck and Saugerties Members of the Schoharie Formation along Route 85, Clarksville, New York. Note that RHf is dipping to the northwest and drag folded as the result of thrust faulting. Also see Ver Straeten (1995; 2007). (1) Modified from Figure 19 of Ver Straeten (2007); (2) Third order eustatic sea level cycles Emsian 5 and Eifelian 1 in relationship to the RHf post-mortem lag deposit as indicated by asterisks (See Ver Straeten, 2007 and Becker et al., 2017); (3) Example of orthoconic nautiloids (f1) exposed along bedrock surface as indicated by arrows. (4) Close-up of drag folding seen in RHf outcrop along Route 85, Clarksville, New York. Note concentration of invertebrate casts and molds indicated by arrow; and, (5) Unweathered surface of RHf exposing dense, bluish-gray limestone adjacent to yellowish-brown to tan weathered surface of $\mathrm{RHf}$ demonstrating characteristic concentrations of invertebrate casts and molds as indicated by arrows. Abbreviations: RHf-Rickard Hill facies; GU-Gumaer Island Member; A-S-Aquetuck and Saugerties Members. 


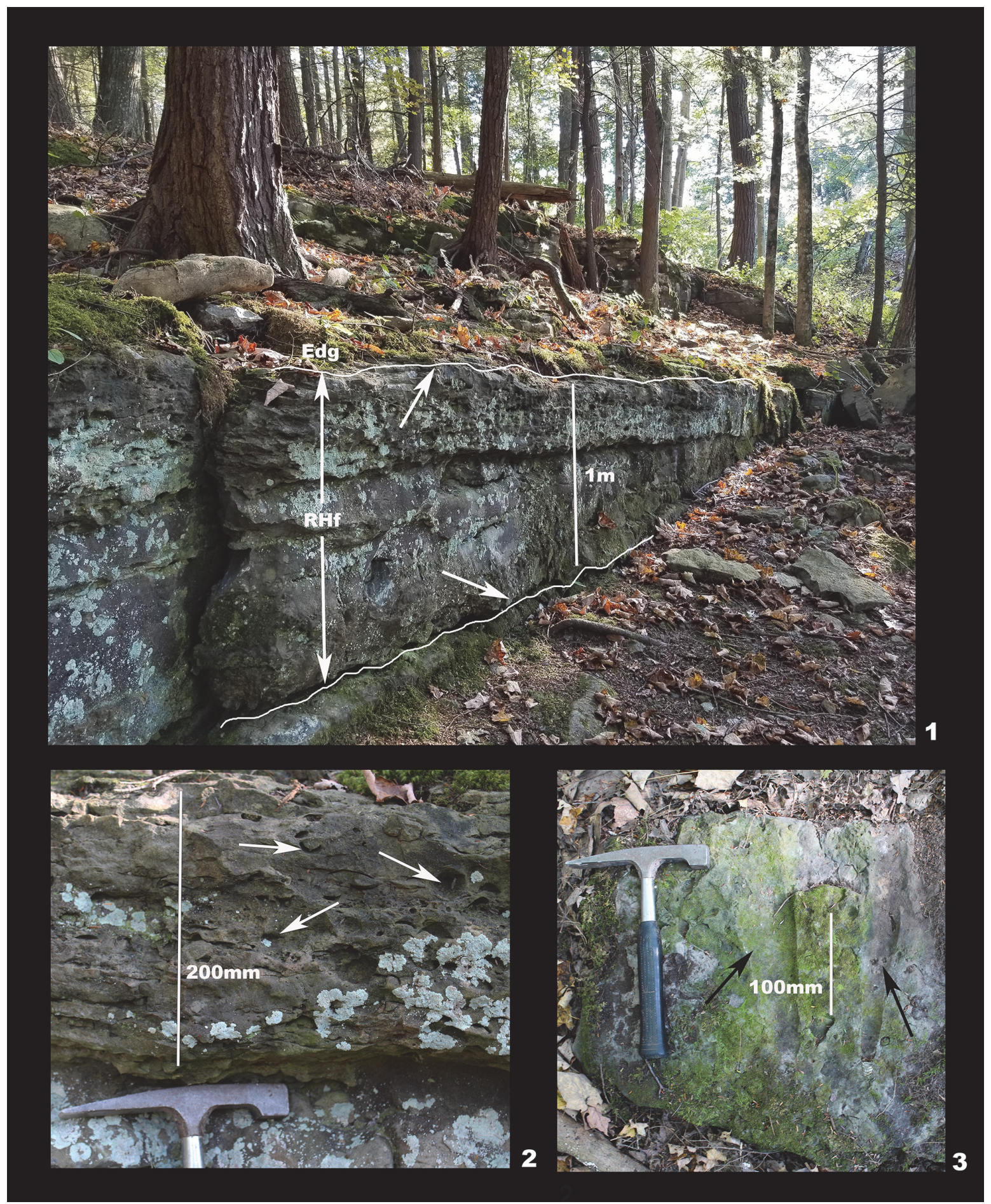

FIGURE 3. Outcrop exposure of the RHf of the Saugerties Member of the Schoharie Formation, Feura Bush, New York. Note distinct erosional surfaces seen in (1) as indicated by lines and arrows; concentration of invertebrate casts and molds of seen in cross-section as indicated by arrows (2); and, (3) molds of orthoconic (f1) nautiloids in RHf talus adjacent to outcrop indicated by arrows. Abbreviations: RHf-Rickard Hill facies; Edg-Edgecliff Member.

glacial erratics that typically represent metamorphic and intrusive igneous rocks. All $\mathrm{RHf}$ glacial erratics show varying degrees of physical and chemical erosion related to plucking and transport within ice, as well as subsequent exposure to meltwater and deposition within acidic soils of regional 
ground moraines. Some RHf glacial erratics retain the blocky, jointed bedding seen in outcrop exposures in Clarksville and Feura Bush, New York, while others show rounding typical of boulders found in regional ground moraines (Figure 4). Currently, RHf glacial erratics have been recovered as far south as High Mountain in Wayne, New Jersey. Although the terminal moraine of the HudsonChamplain Lobe of the Laurentide Ice Sheet occurs $30 \mathrm{~km}$ south of Wayne, New Jersey, no additional $\mathrm{RHf}$ glacial erratics were recovered in this heavily urbanized region. In more rural areas to the east and west of Wayne, extensive field search also yielded no RHf glacial erratics. We attribute these absences to the limited thickness and lateral exposure of the $\mathrm{RHf}$ outcrop belt in the Clarksville, New York, source region and inaccessibility to field study south of Wayne, New Jersey.

In contrast to bedrock in the source region, RHf glacial erratics collected at localities identified in Figure 1 and split along fossiliferous bedding planes show extensive evidence of chemical weathering by dissolution during transport and deposition. Concentrations of shelly exoskeletons, including those from nautiloids, have provided porous and permeable bedding surfaces whereby water percolation has dissolved much of the original shell material and preserved fossils mainly as yellowish-brown to tan iron oxide casts (Figures 513). In some instances, cross-sections of RHf glacial erratics indicate that water percolation moved from all exterior surfaces inward after glacial plucking had taken place (Figure 5.3). Some of the centers of these RHf glacial erratics containing nautiloids maintain their original grayish-blue sandy limestone that is identical to that found in outcrop (Figures 5.3 ; 13.4). Thin films of redeposited calcium carbonate that were dissolved and fluidized during dissolution coat the surfaces of the centers of these $\mathrm{RHf}$ glacial erratics. Partial remains of original shell material from co-occurring brachiopods and rugose corals with thick calcitic exoskeletons can also be identified (e.g., Figures $6.2 ; 9.1 ; 13.1)$. The centers of these RHf glacial erratics that retain some of the original sandy limestone strongly react with dilute hydrochloric acid, while the outer surfaces of iron-oxides show little or no chemical reaction.

Comparison of $\mathrm{RHf}$ petrographic thin sections further demonstrates limestone dissolution in bedrock from Clarksville, New York relative to that found in glacial erratics from Wayne, New Jersey (Figure 5.1-2). In the RHf bedrock sample, the majority of the matrix as observed in cross-polar- ized light is distinctly calcite with sub-angular to sub-rounded quartz grains and calcite cement. In the RHf glacial erratic sample, much of the original calcite has been lost as observed in cross-polarized light and consists primarily of the original subangular to sub-rounded quartz grains that have resisted chemical erosion via dissolution during glacial transport and deposition. In addition to the observed loss in density, dissolution has also resulted in the exposure and preservation of many delicate anatomical and taphonomic features seen in the RHf glacial erratic nautiloid assemblage. These features include: 1) suture patterns; 2) shell ornamentation consisting of nodes and megastriae; 3 ) invertebrates preserved on and within the body chambers and phragmocones; and, 4) bedding planes with multiple orthoconic nautiloids that display similar orientations (Figures 6-13; Wendt, 1995).

Some of the RHf glacial erratics containing nautiloids have been transported as much as 200 $\mathrm{km}$ from the Clarksville, New York, source region into the northern New Jersey Piedmont and deposited approximately 18,500 y.b.p. (Becker and Bartholomew, 2013; Becker et al., 2016; 2017). According to Rayburn et al. (2015), the HudsonChamplain Lobe of the Laurentide Ice Sheet advanced through southern New York and northern New Jersey at a rate of $40 \mathrm{~m} / \mathrm{year}$. This suggests that physical and chemical erosion during glacial ice transport on some of the $\mathrm{RHf}$ nautiloids occurred for at least 5,000 years and exposed some of the taphonomic features identified in this study.

\section{DESCRIPTION OF THE RHF NAUTILOID ASSEMBLAGE}

\section{Orthoconic and Coiled Forms}

The current RHf nautiloid assemblage was collected over the last decade and consists of 129 specimens including isolated individuals, as well as larger blocks weighing up to $50 \mathrm{~kg}$ and preserving as many as seven incomplete individuals along a single bedding surface (Table 1). No complete shells with intact body chambers and unbroken phragmocones were recovered in RHf glacial erratics. Although detailed taxonomic treatment of the RHf nautiloids is beyond the scope of this study, it appears evident to us that it will be necessary to revise the 43 species tabulated by Grabau (1906) and originally classified by Hall (1879) and his successors. We view these classifications to be based mainly on conch form and other features that in 

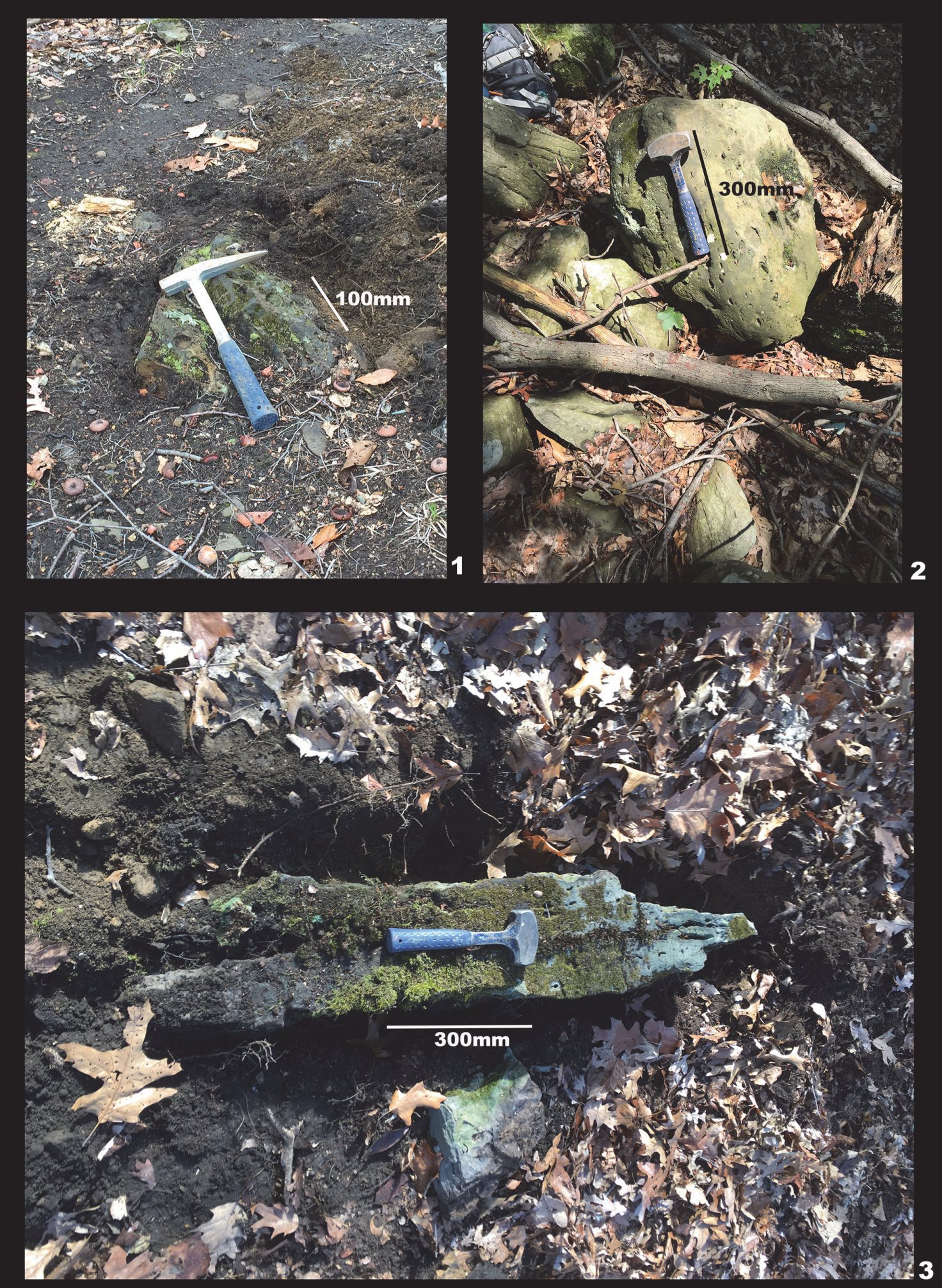

FIGURE 4. Glacial erratics of the RHf as seen in the Lower Hudson Valley of New York and northern New Jersey Piedmont. Note both rounded (1-2) and blocky (3) types of glacial erratics, numerous casts and molds similar to outcrop exposures as seen along exterior surfaces, and burial in regional soils. Orthoconic (f1) and coiled (f2) nautiloids described in this report and seen in Figures 6.2, 10.1, and 13.3 were recovered along the interior bedding surfaces in these RHf glacial erratics. 


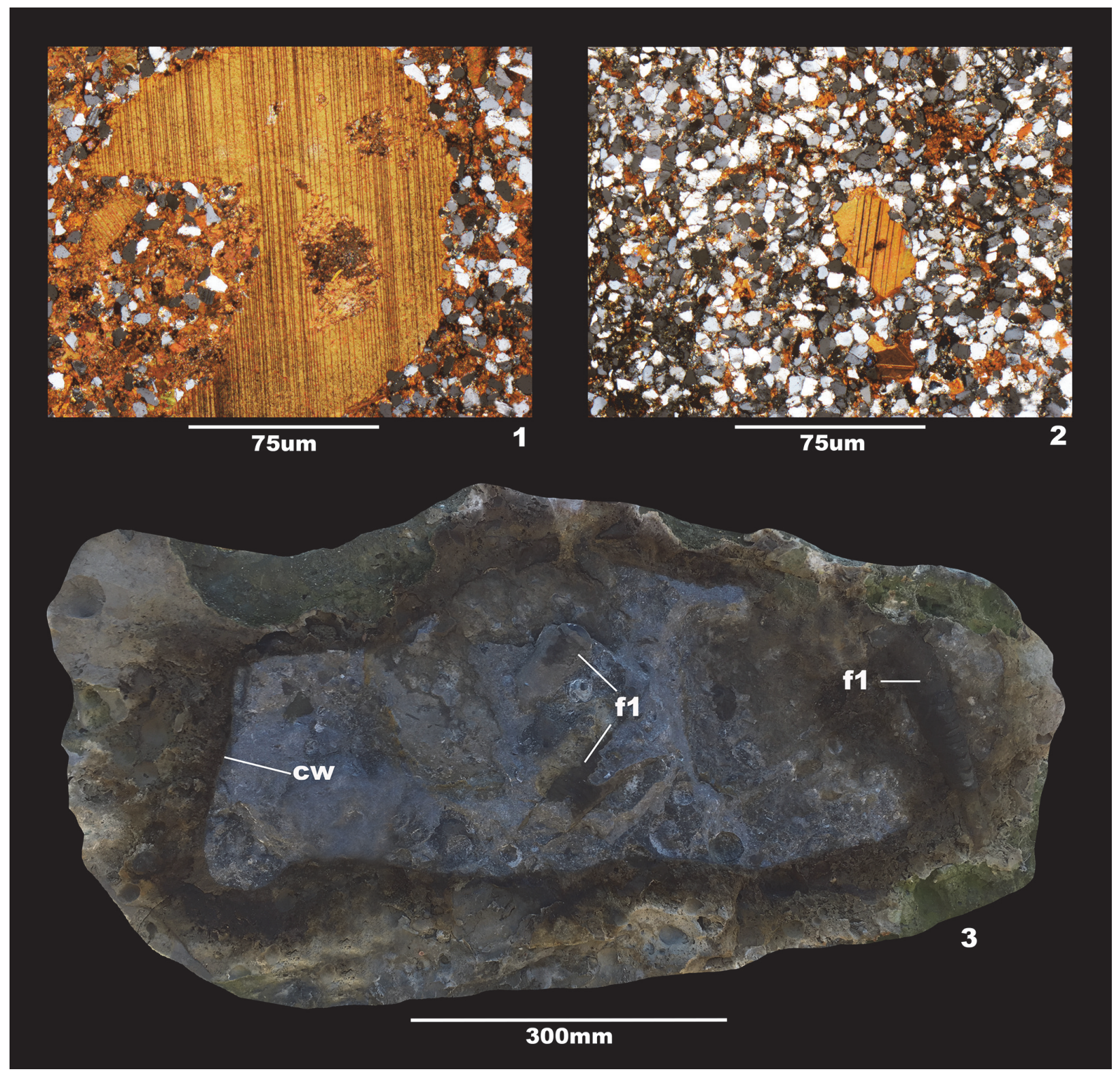

FIGURE 5. Thin section petrographic comparison of RHf outcrop (1) to that seen in glacial erratics (2) and large glacial erratic (3) split along bedding plane demonstrating concentric chemical weathering rind and (f1) nautiloids. Note the overall loss of original calcite via dissolution between outcrop and glacial erratic thin sections and the chemically resistant nature of the sub-angular to sub-rounded quartz grains. Abbreviations: f1-form 1; cw-chemical weathering rind.

many instances are ontogenetic, ecophenotypic, or clearly not of taxonomic significance.

In both outcrop and glacial erratics, RHf nautiloids are preserved along specific bedding planes and do not permit observation of the entire suture pattern, nodes, or megastriae across the dorsal, lateral, and ventral surfaces. Additionally, the opportunity to remove RHf nautiloids from the encasing matrix in most instances is either limited or not possible. In this regard, multiple specimens belonging to the same species show differences in these diagnostic features when viewed in different bedding plane orientations (e.g., Pohle and Klug, 2018). For these reasons and those identified above, our RHf nautiloid analysis in Table 1 recognizes two general forms that represent multiple species. These two forms include orthoconic (f1) and coiled (f2) forms that are separated into three categories including: 1) partial body chambers; 2) partial phragmocones; and 3) partial body cham- 


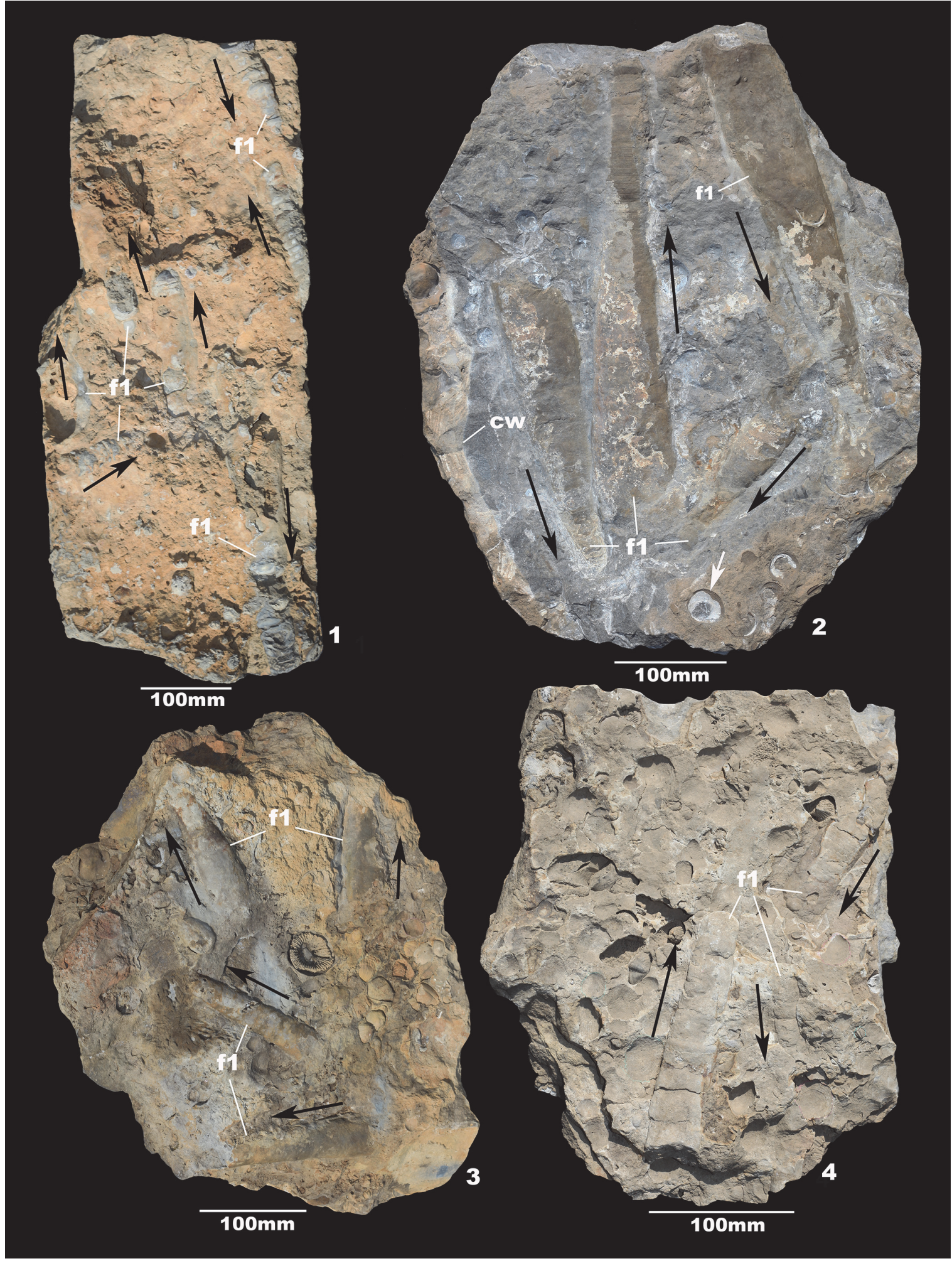

FIGURE 6. Orthoconic nautiloid casts belonging to (f1) from RHf glacial erratics demonstrating similar orientations on bedding surfaces as indicated by arrows. Note differences in chemical weathering as seen in color variations along bedding surfaces. The largest (f1) nautiloids recovered during this study occur on (2) which also contains thin films of redeposited calcitic shell material that were dissolved and fluidized during chemical weathering and dissolution. Original shell material of brachiopods indicated by white arrow in (2). Abbreviations: f1-form 1; cw-chemical weathering rind. 


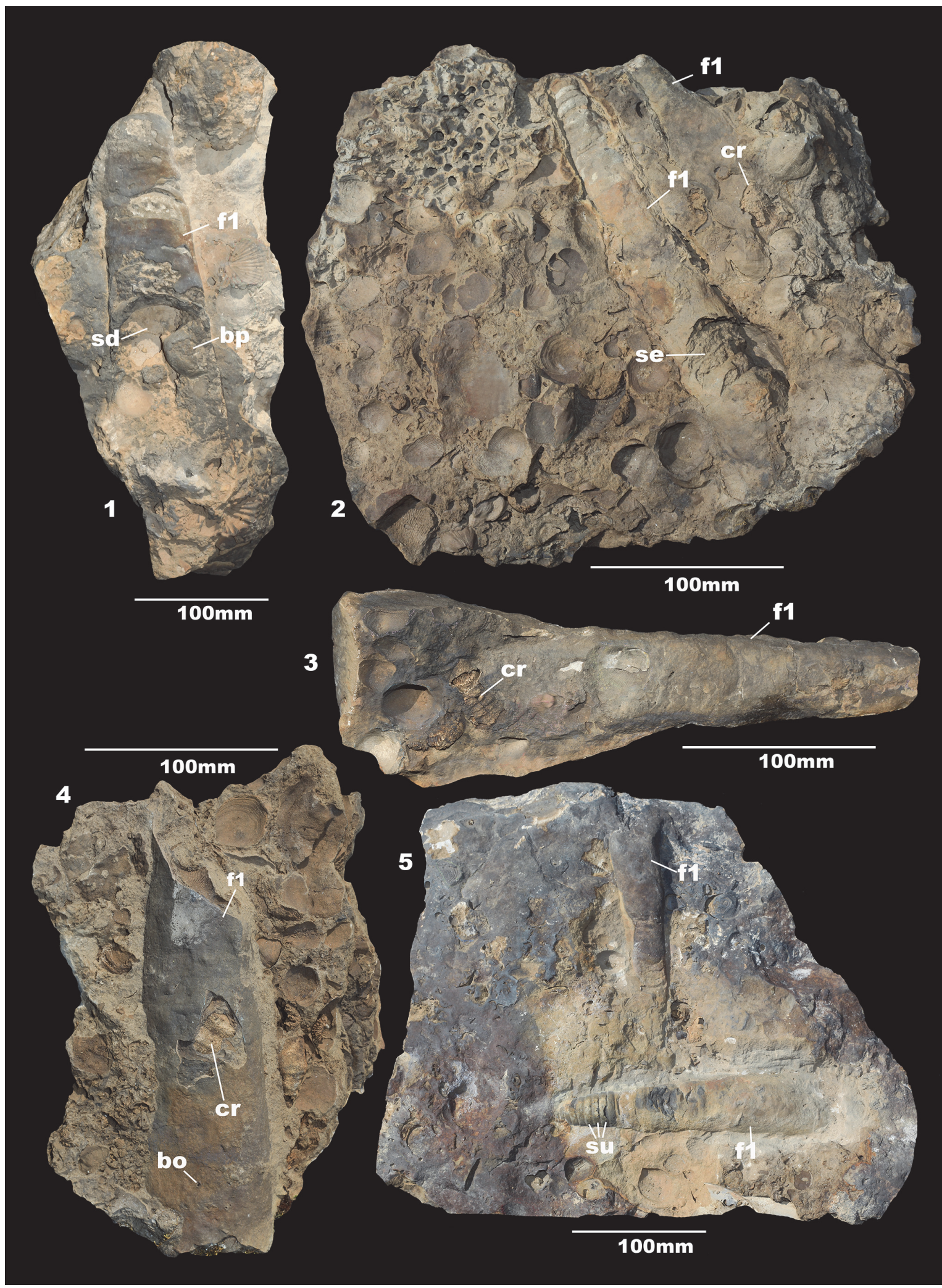

FIGURE 7. Orthoconic nautiloid casts belonging to (f1) from RHf glacial erratics demonstrating brachiopods and rugose corals within body chambers and phragmocones $(1,3,4)$ and chemical erosion exposure of suture pattern and septa $(2,5)$. Abbreviations: f1-form 1; bp-brachiopod; sd-sediment infill; cr-rugose coral; su-suture; se-septa; boshell bioerosion. Note numerous brachiopods and corals along bedding planes in (2) and (4). 


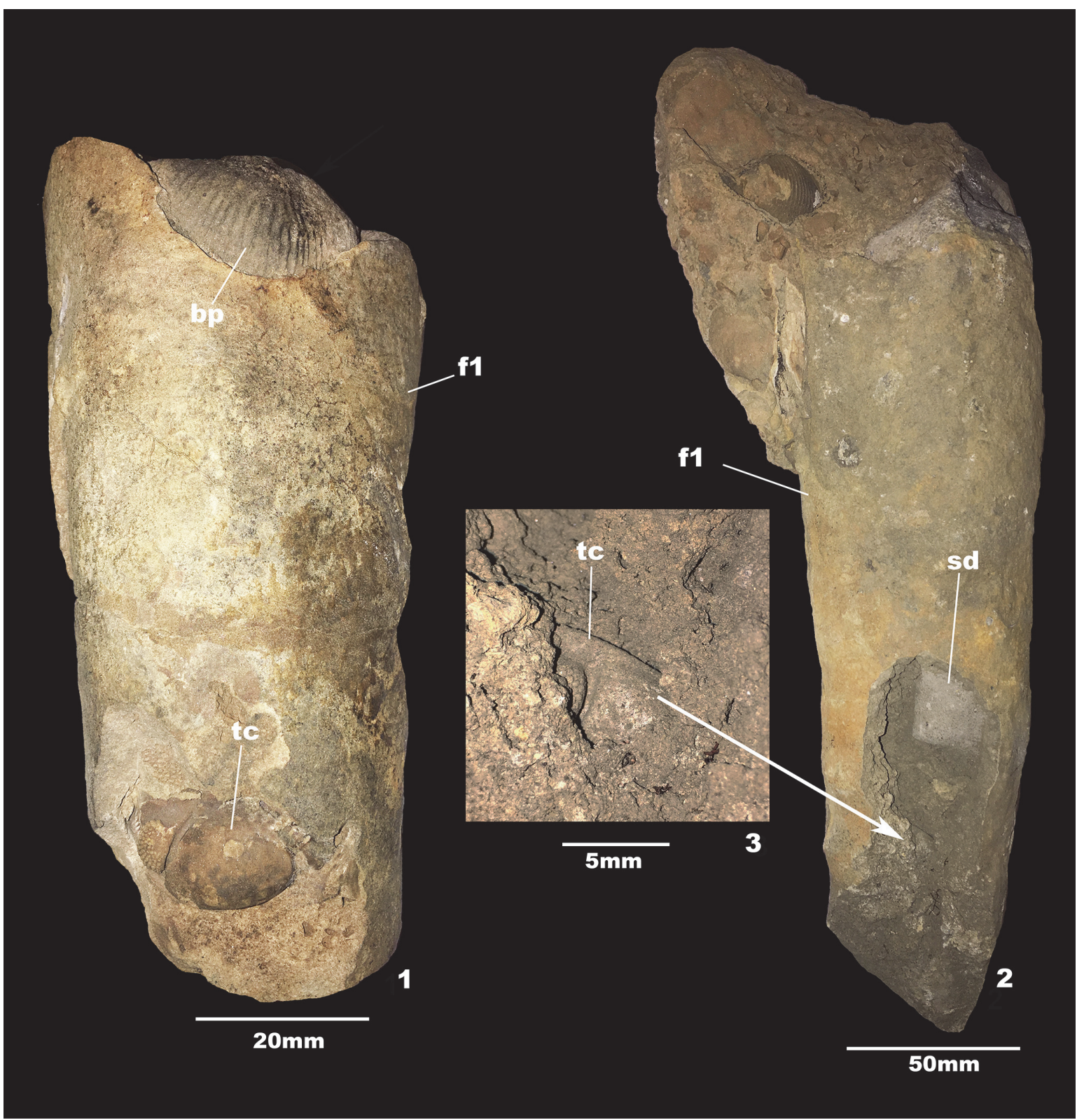

FIGURE 8. Orthoconic nautiloid casts belonging to (f1) from RHf glacial erratics demonstrating body chambers filled with sediment, cephala from the trilobite and brachiopods (1, 2; 3-inset). Abbreviations: f1-form 1; bp-brachiopod; sdsediment infill; tc-trilobite cephalon.

bers attached to partial phragmocones. In Table 1, partial body chambers represent the least frequently encountered $\mathrm{RHf}$ nautiloids while partial phragmocones and partial body chambers attached to partial phragmocones occur in roughly equal percentages. Currently, orthoconic forms belonging to (f1) comprise $88.4 \%$ of the total $\mathrm{RHf}$ assemblage and in this regard resemble all prior aforementioned nautiloid studies from the Schoharie Formation.

\section{Preservation of RHf Nautiloids}

In the RHf glacial erratic assemblage, some of the largest (f1) nautiloids show distinct relative orientations along bedding surfaces and occasionally preserve remains of original shell material (Figure 6 ). Many of the body chambers and phragmocones of both (f1) and (f2) RHf nautiloids are filled with sediment containing disarticulated trilobites, brachiopods, and corals that have been exposed through chemical erosion inside of the shell (e.g., Figures $7.1-5 ; 8.1-3 ; 9.4 ; 10.2 ; 11.3-4 ; 13.1)$. In 


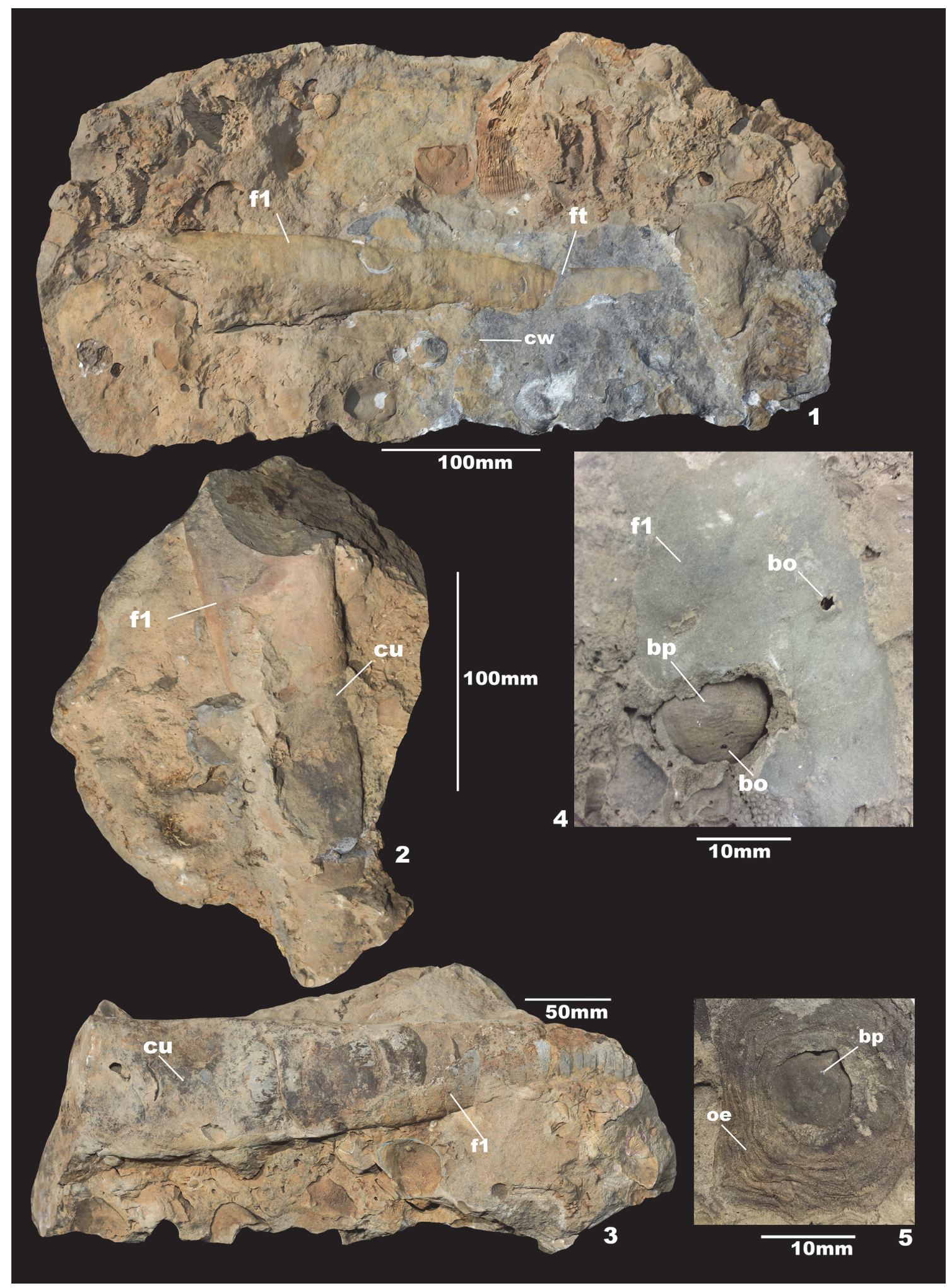

FIGURE 9. Orthoconic nautiloid casts belonging to (f1) from RHf glacial erratics demonstrating crushed and faulted conchs (1-3), bored body chamber with bored brachiopod inside the body chamber (4), and organic encrustation of a brachiopod valve (5). Note differences in chemical erosion in (1) as well as original shell material. Abbreviations: f1form 1; ft-fault; cw-chemical weathering rind; cu-crushed body chamber; bp-brachiopod; bo-shell bioerosion; oeorganic encrustation. 


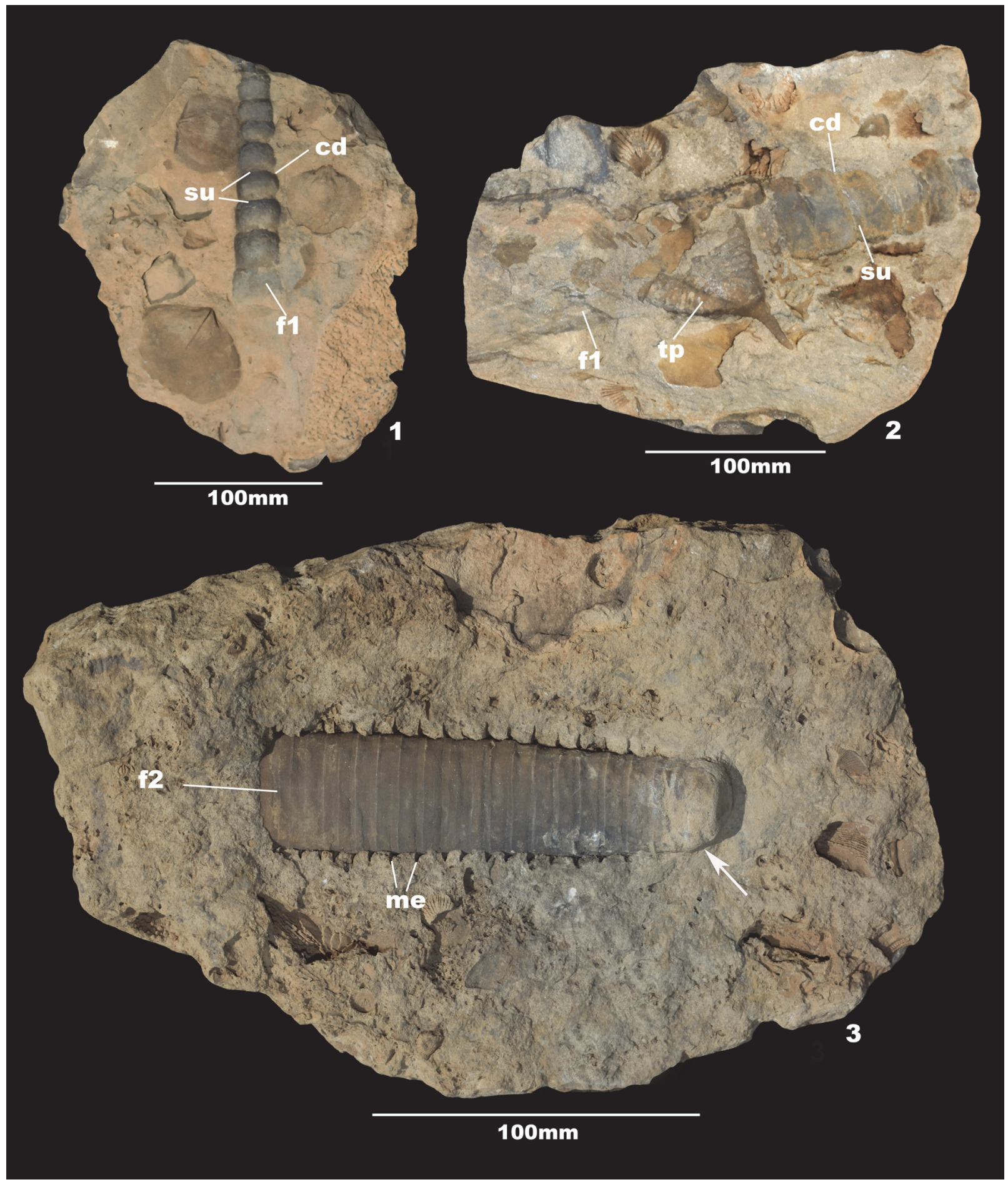

FIGURE 10. Orthoconic and coiled nautiloid casts belonging to (f1) and (f2) from RHf glacial erratics. (1-2) Simple suture pattern that is distinctly rounded and appears bead-like due to cameral deposits and a pygidium with telson of the trilobite crushed against body chamber as indicated by arrow along with several casts of brachiopods; (3) Wellpreserved example of (f2) cast demonstrating simple suture pattern, megastriae and slight coiling out of the bedding plane in phragmocone portion as indicated by arrow. Abbreviations: f1-form 1; cd-cameral deposits; tp-trilobite pygidium; f2-form 2; me-megastria. 


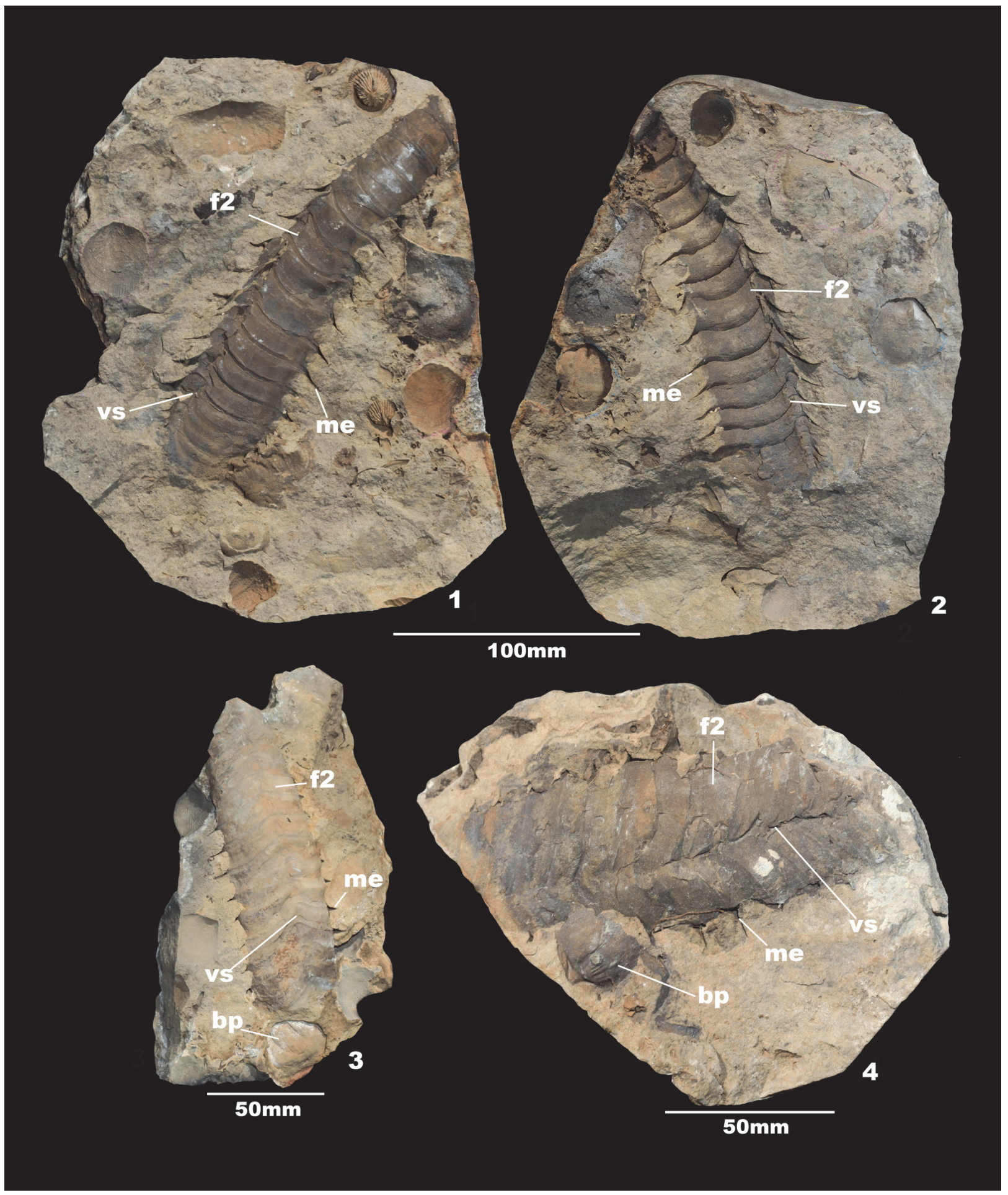

FIGURE 11. Coiled nautiloid casts and mold belonging to (f2) from RHf glacial erratics with a distinct chevron pattern in the ventral sinus and megastriae positioned where the shell wall and septum meet. Note brachiopod casts preserved within and adjacent to body chambers (1, 3, 4-casts and 2-mold). Abbreviations: (f2)-form 2; me-megastria; vs-ventral sinus; bp-brachiopod. 


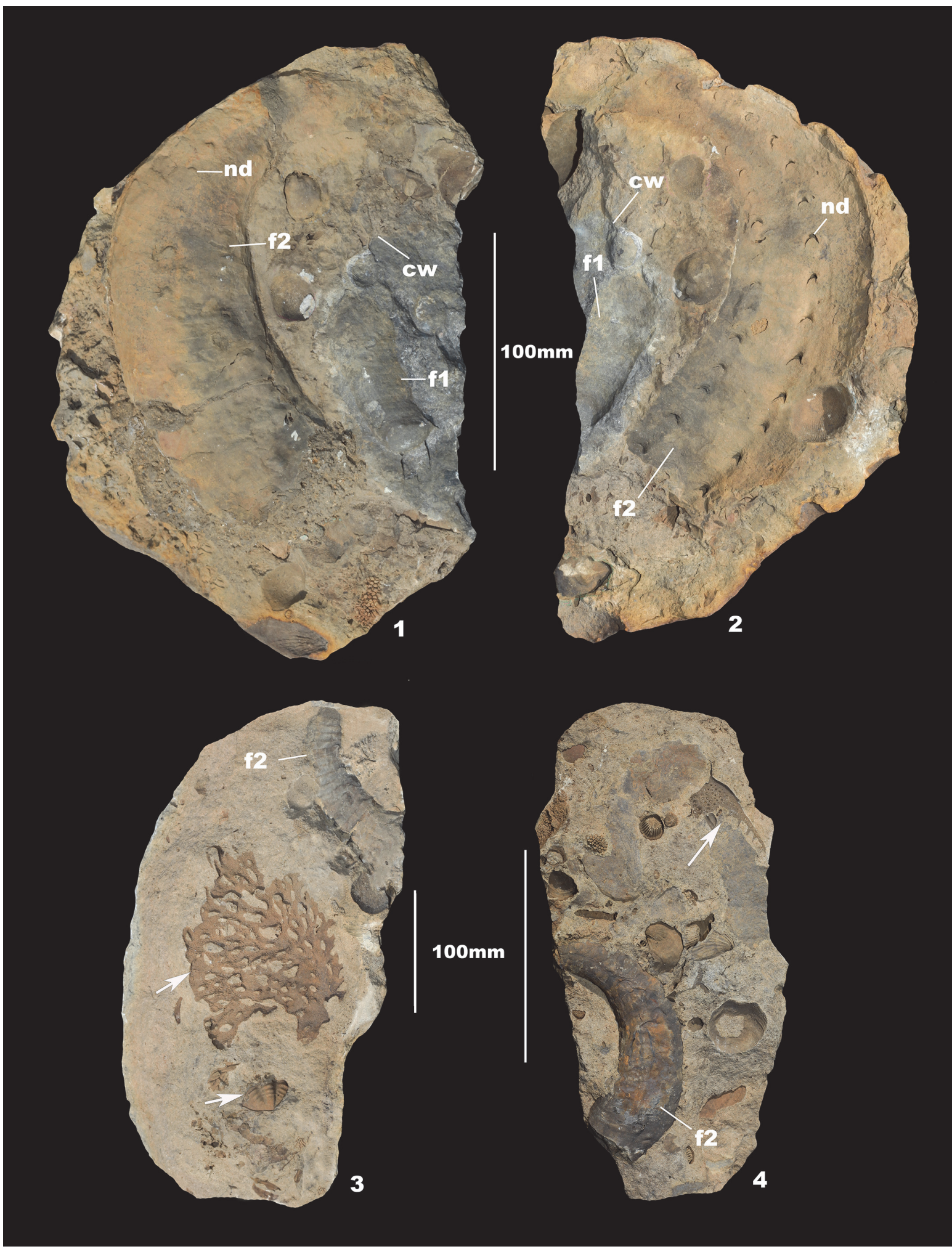

FIGURE 12. Coiled nautiloid casts and molds belonging to (f2) from RHf glacial erratics. Note brachiopods preserved near the opening of the body chamber in (1-2); branching coral and trilobite pygidium in (3) and genial spine of trilobite in (4) indicated by arrows; (1, 3, 4-casts and 2-mold). The largest (f2) nautiloid recovered during this study occurs on (1-2). Abbreviations: f2-form 2; bp-brachiopod; nd-node; cw-chemical weathering rind; f1-form 1. 


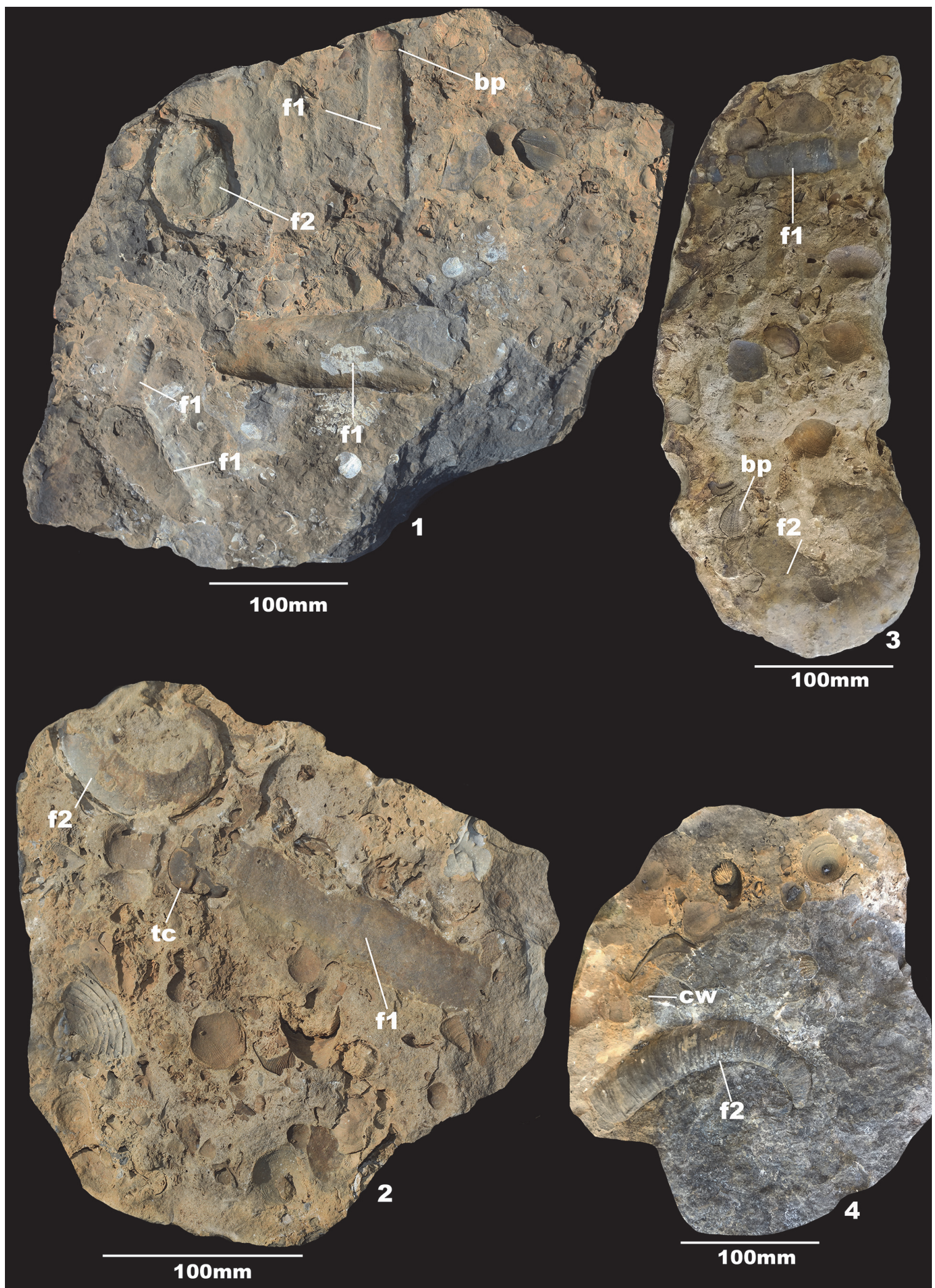

FIGURE 13. Co-occurrence of (f1) and (f2) nautiloids along with trilobite cephala and brachiopods within body chambers (1-3); and (4) distinct differences in stages of chemical weathering of an (f2) nautiloid as seen in RHf glacial erratics. Note numerous trilobites, brachiopods and corals along bedding planes in (1-3). Abbreviations: f1-form 1; f2-form 2; bp-brachiopod; tc-trilobite cephalon; $\mathrm{cw}$-chemical weathering rind. 
TABLE 1. Shell completeness data of RHf nautiloids compiled from glacial erratics occurring in the Lower Hudson Valley of New York and northern New Jersey Piedmont. RHf nautiloid analysis includes 129 specimens and recognizes two general forms that represent multiple species and include: 114 orthoconic (f1) and 15 coiled (f2) forms. The RHf nautiloid assemblage is reposited in the paleontological collections of the Department of Environmental Science, William Paterson University (WPU-ENVSCI-RHfNC:1-129).

\begin{tabular}{lcccc}
\hline \multicolumn{1}{c}{$\begin{array}{c}\text { Forms } \\
\mathbf{( 1 )} \text { and (2) }\end{array}$} & $\begin{array}{c}\text { Percent of total } \\
\text { assemblage }\end{array}$ & $\begin{array}{c}\text { Average maximum } \\
\text { diameter } \\
\mathbf{( c m )}\end{array}$ & $\begin{array}{c}\text { Average length } \\
\mathbf{( c m )}\end{array}$ & $\begin{array}{c}\text { Number of } \\
\text { camerae }\end{array}$ \\
\hline Partial body chamber & 14.2 & $4.58 \pm \sigma=1.45$ & $10.18 \pm \sigma=6.08$ & none \\
$\begin{array}{l}\text { Partial phragmocone } \\
\text { Partial body chamber attached to } \\
\text { partial phragmocone }\end{array}$ & 39.4 & $3.71 \pm \sigma=1.48$ & $12.51 \pm \sigma=5.64$ & $16.13 \pm \sigma=7.55$ \\
\hline
\end{tabular}

some (f1) RHf nautiloids, body chambers and phragmocones are fractured, crushed, and offset by small scale faulting during post-depositional tectonism (Figure 9.1-3). In other examples, (f1) RHf nautiloids and brachiopods show evidence of shell bioerosion and organic encrustation of a brachiopod cast (Figures $7.4 ; 9.4-5)$. The suture pattern in most examples of (f1) and (f2) RHf nautiloids is straight and simple and in several examples appears rounded and bead-like due to cameral deposits or chevron-patterning in the ventral sinus (Figures 10.1-2; 11.1-4; 13.3). Exceptionally wellpreserved examples of (f2) RHf nautiloids display megastriae and dorsolateral and ventrolateral nodes on the shell flanks (Figures 10.3; 11.1-2; 12.1-2). Along some of the larger bedding surfaces as seen in Figure 13.1-3, examples of both (f1) and (f2) $\mathrm{RHf}$ nautiloids co-occur with numerous trilobites, brachiopods, and corals that are disarticulated and show multiple orientations. In Figure 13.4, distinct differences in chemical weathering of an (f2) RHf nautiloid can be observed along a bedding surface at during different stages of dissolution. The coiling, ornamentation, and suture pattern are observable in both grayish-blue bedrock and yellowish-brown to tan glacial erratic stages.

\section{DISCUSSION}

\section{Nautiloids in the RHf}

To date, the most comprehensive study of nautiloids found in the Schoharie Formation still remains that of James Hall's (1879) original species identifications and illustrations. In fact, several illustrations in Hall (1879) even include fragments of brachiopods and corals occurring within the body chambers and phragmocones of large orthoconic nautiloids, as well as conchs that are crushed. Explanations of these nautiloids by Hall (1879) include no taphonomic details, nor do any occur in subsequent studies of the Schoharie Formation to date. In this regard, our analysis of the RHf nautiloid assemblage compiled in Table 1 utilizes recent studies of Paleozoic nautiloid taphonomy to interpret depositional environment, concentration, size class, and local sea level history of the RHf source provenance in eastern New York State.

\section{Depositional Environment of RHf Nautiloids}

From Table 1, we infer that the RHf nautiloid assemblage represented part of a localized, biohermal community occurring along the lower shoreface of an inner shelf patch reef and was comprised of a diverse and abundant array of benthopelagic animals (e.g., Brett et al., 2007; Barskov et al., 2008; Manda and Turek, 2011). Other cooccurring and disarticulated benthic invertebrates including brachiopods, corals, and trilobites support this interpretation (Williams, 1980; Fagerstrom, 1983; Brett and Baird, 1986; Kaufmann, 1998; Becker and Bartholomew, 2013). It is also interesting that the $\mathrm{RHf}$ shelf biohermal community in the northern Appalachians currently contains little or no evidence of ammonoids that had diversified globally into several distinct lineages by the late Emsian, including Anarcestaceans and Agoniatitaceans (House, 1978; Becker and Kullmann, 1996; Kröger, 2005; Klug and Korn, 2004; Pohle and Klug, 2018). To date, only a single, small, poorly preserved apparently agoniatitid goniatite named Convoluticeras (?) schohariae is known from the Schoharie Formation in eastern New York (Flower, 1978; Linsley, 1994). In this regard, prior studies indicate that extensive post-mortem drift of empty Paleozoic nautiloid shells is uncommon as most shells sink, coming to rest on the sea floor in the same locality inhabited by the living animals (e.g., Boston and Mapes, 1991; Hewitt and Westermann, 1996; Wani, 2007; Kröger et al., 2009). This indicates that the $\mathrm{RHf}$ nautiloids have not 
been transported from other areas within the northern Appalachian basin or adjacent basins and preserve the depositional environment characteristics of the living animals in this localized region of eastern New York.

\section{Nautiloid Concentration and Size Class}

The RHf nautiloid assemblage is dominated by large, incomplete specimens (Table 1) where their state of preservation indicates concentration likely occurred as a result of multiple exhumation and reburial events (Becker et al., 2017). This taphonomic condition could have also resulted in destruction of their shells. We attribute this lack of destruction to thicker shell material comprising larger conchs that dominate the $\mathrm{RHf}$ nautiloid assemblage. Additionally, the sandy limestone comprising the $\mathrm{RHf}$, in both outcrop and glacial erratics, contains no pebbles or large clasts as seen in other lower and middle Paleozoic formations in eastern New York State (e.g., Ver Straeten, 2009). Such larger clasts in these formations are typical of more proximal locations to ancestral shorelines and terrigenous sediment sources that would have resulted in greater destruction to the accumulating $\mathrm{RHf}$ nautiloids and other invertebrates during initial deposition and reworking. Nautiloids and other invertebrates may have also been concentrated during times of condensed sedimentation in this region of the inner shelf and as a result formed temporary hardgrounds (e.g., Griffing and Ver Straeten, 1991). These hardgrounds in the $\mathrm{RHf}$ contain both brachiopods and nautiloids with shell bioerosion and organic encrustations that imply prolonged exposure on the sea floor (Figures 7.4; 9.4-5); (e.g., Cornell et al., 2003; Cherns et al., 2008). Although it is not possible to reconstruct ancestral paleocurrents from the eroded and transported RHf glacial erratics, Figure 6 indicates that bottom currents oriented some of the larger conchs belonging to (f1) (e.g., Wendt, 1995). Along with these current-oriented conchs, the fragmentary nature, large overall size, and multiple orientations of associated invertebrates seen on the same bedding planes attest to the fact that scouring and winnowing occurred during the development of the localized post-mortem lag deposit comprising the RHf (Figures 6-13; Table 1; e.g., Brett and Baird, 1986).

The shell data reported in Table 1 are also consistent with the viewpoint that the $\mathrm{RHf}$ nautiloids in our glacial erratic assemblage were concentrated during multiple exhumation and reburial events, as no specimens in the assemblage are complete. These data also show that there are no small shells or shell fragments of nautiloids preserved in the RHf glacial erratics. One possible explanation for this skewed composition is that the remains of small individuals were winnowed away by the same hydrodynamic regime that oriented the larger orthoconic nautiloids. However, this situation is unlikely because the $\mathrm{RHf}$ also contains a rich representation of small brachiopods, bryozoans, corals, and trilobite skeletal elements less than a few centimeters that would have also been removed had such winnowing taken place (Becker and Bartholomew, 2013; Becker et al., 2017). In this regard, it is also noteworthy that dissolution during glacial transport and deposition has not removed evidence of these small invertebrates, whereas no small juvenile nautiloids were identified in our RHf glacial erratic assemblage.

An alternative explanation proposed in this study for the large size of the nautiloids found in the $\mathrm{RHf}$ assemblage and Table 1 may be related to a life and reproductive strategy in which small juveniles lived separately and in a different depositional environment. Examples of juvenile and adult nautiloids from the Devonian occurring in different depositional environments that support this explanation include: 1) Wadleigh Formation of southeastern, Alaska, and Holy Cross Mountains near Chęciny, Poland, that contain multiple beds and concretions of concentrated juvenile nautiloids (Soja et al., 1996; Rakociński and Borcuch, 2016); 2) Cherry Valley Limestone of central New York that contains concentrations of large co-occurring orthoconic nautiloids and ammonoids (Klofak, 2002); and, 3) Třebotov and Choteč Limestones of the Prague Basin, Czech Republic that contains both juvenile and adult coiled nautiloids separated into distinct size populations (Manda and Turek, 2011). Proposed life and reproductive strategies in these studies that resulted in separation of juvenile and adult populations included: spawning, predation, and the efficiency of calcification in embryonic nautiloids in warm shallow water. It is also noteworthy that nautiloid assemblages in the Wadleigh Formation, Holy Cross Mountains and Cherry Valley Limestone were preserved in the same depositional environment inhabited by the living animals and were concentrated by storm events and sea level cyclicity (Soja et al., 1996; Klofak, 2002; Rakociński and Borcuch, 2016).

\section{Sequence Stratigraphy of the RHf Nautiloids}

The sequence stratigraphy for the RHf of the Saugerties Member of the Schoharie Formation 
and Lower-Middle Devonian transition in eastern New York and the Helderberg Mountains region has been previously studied by Brett and Ver Straeten (1994) and in subsequent publications including Ver Straeten $(1995 ; 2007)$ and Brett et al. (2007; 2011). This sequence stratigraphy provides a framework by which the concentration of orthoconic and coiled nautiloids within the RHf can be evaluated (e.g., Brett, 1995). By comparison, this sequence stratigraphy also indicates that the RHf resides at the boundary between third order eustatic sea level sequence boundary Emsian Cycle 5 and Eifelian Cycle 1, as well as the contact between the uppermost Schoharie and lowermost Onondaga Formations (Figure 2.2). It is noteworthy that the transition between the Schoharie and Onondaga Formations in this localized area where the RHf occurs differs from that found in central and western New York, as well as other areas along the outcrop belt to the east. In eastern New York, the transition between these two formations is gradational and relatively conformable, while in central and western New York a major break in deposition occurs that locally becomes amalgamated with the pre-Schoharie and Wallbridge Unconformities (Goldring and Flower, 1942; Oliver, 1954; Johnsen and Southard, 1962; Brett and Ver Straeten, 1994; Ver Straeten, 1995; 2007). These differences across the contact between the Schoharie and Onondaga Formations also reflect complex structural controls of an eastward migrating peripheral bulge during the Acadian Orogeny and their resulting influence on late Emsian-early Eifelian platform bathymetry (Brett and Ver Straeten, 2000; Ver Straeten, 2010).

We interpret the distinct nature of the $\mathrm{RHf}$ nautiloid assemblage to be the product of wavebased erosion and deposition along the lower shoreface of the inner shelf within a localized area in eastern New York. As originally proposed in Becker et al. (2017), invertebrate fossils including nautiloids found in the RHf were concentrated during third order eustatic sea level regression falling stage Emsian Cycle 5 of Ver Straeten (2007) and as part of a shallowing upward cycle bounded below and above by the sub-Aquetuck and subEdgecliff unconformities. During this event, the RHf fauna was subjected to multiple episodes of exhu- mation and reburial as wave base eroded into the shallow shelf in this localized region of eastern New York during falling sea level and storm events. The resulting concentration of nautiloids and other invertebrate fossils therefore represent time-averaged and post-mortem lag accumulations of hydrodynamically sorted and fragmented exoskeletons (Kidwell and Bosence, 1991; Holland et al., 1994; Brett, 1995; Histon, 2012). Storm events would have also been responsible for reworking brachiopods, corals, and trilobites within the phragmocones and body chambers of nautiloids, as well as associated sediment infilling (e.g., Davis et al., 2001). Additional reworking and preservation of the $\mathrm{RHf}$ nautiloid assemblage occurred during subsequent transgression and sediment burial during Eifelian Cycle 1.

\section{CONCLUSIONS}

To our knowledge, this study is the first of its kind to interpret the taphonomy of a nautiloid concentration utilizing glacial erratics of known outcrop source provenance and sequence stratigraphic principles. As observed in the aforementioned Devonian studies, we hypothesize that the overall large size of the $\mathrm{RHf}$ nautiloids and absence of small individuals demonstrate life and reproductive strategies where juveniles and adults can be found in different depositional environments. These interpretations rely upon a combination of physical and chemical weathering that occurred during and after glacial transportation and deposition within the Hudson-Champlain Lobe of the Laurentide Ice Sheet and between the Helderberg Mountains region of New York and the northern New Jersey Piedmont. Recent study of Lower and Middle Devonian invertebrate assemblages in non-RHf glacial erratics in the Lower Hudson Valley of New York and northern New Jersey Piedmont including the Oriskany, Glenarie, and Mt. Marion formations demonstrate similar elements of physical and chemical erosion (Maisch et al., 2017). These non$\mathrm{RHf}$ glacial erratics also have distinct lithologies and fossil assemblages and provide additional opportunities to observe taphonomy in the original bedrock source region utilizing the approaches provided in this study. 


\section{REFERENCES}

Barskov, I., Boiko, M., Konovalova, V., Leonova, T., and Nikolaeva, S. 2008. Cephalopods in the marine ecosystems of the Paleozoic. Paleontological Journal, 42:1167-1284. http://doi.org/ $10.1134 / \mathrm{S} 0031030108110014$

Becker, M. and Bartholomew, A. 2013. Rickard Hill facies of the Schoharie Formation (Lower Devonian) glacial erratics from the Preakness Formation (Lower Jurassic) of High Mountain, Passaic County, New Jersey. Atlantic Geology, 49:194-203.

Becker, M., Bartholomew, A., and Maisch, H. 2016. Pleistocene ice flow direction indicated by Terataspis grandis (trilobite) bearing erratics from the Rickard Hill facies of the Saugerties Member of the Schoharie Formation (Lower Devonian). Northeastern Geosciences, 34:7-11.

Becker, M., Chamberlain, R., Maisch, H., Bartholomew, A., and Chamberlain, J. 2017. Trilobites from the Rickard Hill facies of the Saugerties Member of the Schoharie Formation, eastern New York (upper Emsian and Lower Devonian): a case study in taphonomy and sequence stratigraphy from glacial erratics. Atlantic Geology, 53:117-132. http://doi.org/10.4138/ atlgeol.2017.011

Becker, T. and Kullmann, J. 1996. Paleozoic ammonoids in space and time, p. 711-753. In Landman, N., Tanabe, K., and Davis, R., (eds.), Ammonoid Paleobiology. Springer, Boston, Massachusetts. http://doi.org/10.1007/978-1-4757-9153-2_17

Boston W. and Mapes, R. 1991. Ectocochliate cephalopod taphonomy, P. 220-240. In Donovan, S. (ed.), The Processes of Fossilization. Belhaven Press, London.

Brembs, R., Heinemann, A., Scimeca, R., Maisch, H., Becker, M., and Bartholomew, A. 2015. Cephalopod diversity in the Lower Devonian Schoharie Formation: A unique opportunity for reassessment of diversity from glacial erratics. Geological Society of America Abstracts with Programs, 47:138.

Brett, E. 1995. Sequence stratigraphy, biostratigraphy, and taphonomy in shallow marine environments. Palaios, 10:597-616. http://doi.org/10.2307/3515097

Brett, C. and Baird, G. 1986. Comparative taphonomy: a key to paleoenvironmental interpretation based on fossil preservation. Palaios, 1:207-227. http://doi.org/10.2307/3514686

Brett, C., Baird, G., Bartholomew, A., DeSantis, M., and Ver Straeten, C. 2011. Sequence stratigraphy and a revised sea-level curve for the Middle Devonian of eastern North America. Palaeogeography, Palaeoclimatology, Palaeoecology, 304:21-53. https://doi.org/10.1016/ j.palaeo.2010.10.009

Brett, E., Hendy, A., Bartholomew, A., Bonelli, J., and McLaughlin, P. 2007. Response of shallow marine biotas to sea-level fluctuations: A review of faunal replacement and the process of habitat tracking. Palaios, 22:228-244. https://doi.org/10.2110/palo.2005.p05-028r

Brett, C., Ivany, L., Bartholomew, A., DeSantis, M., and Baird, G. 2009. Devonian ecologicalevolutionary subunits in the Appalachian Basin: a revision and a test of persistence and discreteness. Geological Society of London, Special Publications, 314:7-36.

Brett, C. and Ver Straeten, C. 1994. Stratigraphy and facies relationships of the Eifelian Onondaga Limestone (Middle Devonian) in western and west central New York State. p. 221270. In Brett, C. and Scatterday, J. (eds.), Fieldtrip Guidebook, New York State Geological Association 68th Annual Meeting.

Cherns, L., Wheeley, J., and Wright, V. 2008. Taphonomic windows and molluscan preservation. Palaeogeography, Palaeoclimatology, Palaeoecology, 270:220-229. https://doi.org/10.1016/ j.palaeo.2008.07.012

Cooper, M. and Mylroie, J. 2015. Cave and Karst Systems of the World. Springer, Heidelberg, New York.

Cornell, R., Brett, C., and Sumrall, C. 2003. Paleoecology and behavior of an edrioasteroiddominated hardground association from tentaculitid limestones in the Early Devonian of New York: a Paleozoic rocky peritidal community. Palaios, 18:212-224. https://doi.org/10.1669/ 0883-1351(2003)018<0212:PATOAE>2.0.CO;2

Davis, R., Fraaye, R., and Holland, C. 2001. Trilobites within nautiloid cephalopods. Lethaia, 34:37-45. https://doi.org/10.1080/002411601300068251

Fagerstrom, J. 1983. Diversity, speciation, endemism and extinction in Devonian reef and levelbottom communities, eastern North America. Coral Reefs, 2:65-70.

Flower, R. 1945. Classification of Devonian nautiloids. American Midland Naturalist, 33:675-724

Flower, R. 1949. New genera of Devonian nautiloids. Journal of Paleontology, 23:74-80. 
Flower, R. 1978. A Schoharie Grit (Devonian, New York) ammonoid. Journal of Paleontology, 52:1001-1003.

Flower, R. and Kummel, B. 1950. A classification of the Nautiloidea. Journal of Paleontology, 24:604-616.

Goldring, W. and Flower, R. 1942. Restudy of the Schoharie and Esopus formations in New York State. American Journal of Science, 240:673-694.

Grabau, A. 1906. Guide to the geology and paleontology of the Schoharie Valley in eastern New York. New York State Museum Bulletin, 92:1-386.

Griffing, D. and Ver Straeten, C. 1991. Stratigraphy and depositional environments of the lower part of the Marcellus Formation (Middle Devonian) in eastern New York, p. 205-334. In Ebert, J. (ed.), Oneonta, New York State Geological Association 63rd Annual Meeting Guidebook.

Hall, J. 1861. Descriptions of new species of fossil from the Upper Helderberg, Hamilton and Chemung Groups; with observations on previously described species. P. 99-109. In Annual Report of the Regents of the University of the State of New York on the Condition of the Cabinet of Natural History, Albany, New York, 14.

Hall, J. 1876. Illustrations of Devonian fossils: Gastropoda, Pteropoda, Cephalopoda, Crustacea, and corals of the Upper Helderberg, Hamilton and Chemung Groups. Albany, New York, 136.

Hall, J. 1879. Palaeontology: Vol. V, Part II, Containing descriptions of the Gastropoda, Pteropoda and Cephalopoda of the Upper Helderberg, Hamilton, Portage, and Chemung Groups. Geological Survey of the State of New York. Charles van Benthuysen and Sons, Albany.

Hewitt, R. and Westermann, G. 1996. Post-mortem behavior of Early Paleozoic nautiloids and paleobathymetry. Paläontologische Zeitschrift, 70:405.

Histon, K. 2012. Paleoenvironmental and temporal significance of variably colored Paleozoic orthoconic nautiloid cephalopod accumulations. Palaeogeography, Palaeoclimatology, Palaeoecology, 367:193-208. https://doi.org/10.1016/j.palaeo.2012.07.008

Holland, C., Gnoli, M., and Histon, K. 1994. Concentrations of Palaeozoic nautiloid cephalopods. Bollettino della Società Paleontologica Italiana, 33:83-99.

House, M. 1978. Devonian ammonoids from the Appalachians and their bearing on international zonation and correlation. Special Papers in Palaeontology, No. 21:1-70.

Johnsen, J. and Southard, J. 1962. The Schoharie Formation in southeastern New York, p. 7-19. In Valentine, W. (ed.), Fieldtrip Guidebook New York State Geological Association 34th Annual Meeting.

Kaufmann, B. 1998. Middle Devonian reef and mud mounds on a carbonate ramp: Mader Basin (eastern Anti-Atlas, Morocco). Geological Society London, Special Publications, 149:417435. https://doi.org/10.1144/GSL.SP.1999.149.01.19

Kidwell, S. and Bosence, D. 1991. Taphonomy and time-averaging of marine shelly faunas, $p$. 115-209. In Allison, P. and Briggs, D. (eds.), Taphonomy: Releasing the Data Locked in the Fossil Record. Plenum, New York.

Klofak, S. 2002. Size classes in ammonoids from the Middle Devonian Cherry Valley Limestone of New York state, USA. Abh Geol Bundesanst, 57:443-457.

Klug, C. and Korn, D. 2004. The origin of ammonoid locomotion. Acta Palaeontologica Polonica, 49: 235-242.

Kröger, B. 2005. Adaptive evolution in Paleozoic coiled cephalopods. Paleobiology, 31:253-268. https://doi.org/10.1666/0094-8373(2005)031[0253:AEIPCC]2.0.CO;2

Kröger, B., Servais, T., and Zhang. Y. 2009. The origin and initial rise of pelagic cephalopods in the Ordovician. PLoS ONE 4: e7262. https://doi.org/10.1371/journal.pone.0007262

Linsley, D. 1994. Devonian Paleontology of New York, Paleontological Research Institution Special Publication, Ithaca, New York, 21.

Maisch, H., Becker, M., Gocklin, C., Chamberlain, J., Dubaldi, M., Bartholomew, A., and Chamberlain, R. 2017. Reconstructing surficial geology in the northern New Jersey Piedmont utilizing fossiliferous glacial erratics from the Lower and Middle Devonian of eastern New York. Geologic Society of America Abstracts with Programs, p. 46-9.

Manda, Š. and Turek, V. 2011. Late Emsian Rutoceratoidea (Nautiloidea) from the Prague Basin, Czech Republic: morphology, diversity and paleoecology. Palaeontology, 54:999-1024. https://doi.org/10.1111/j.1475-4983.2011.01089.x

Oliver, W. 1954. Stratigraphy of the Onondaga limestone (Devonian) in central New York. Geological Society of America Bulletin, 65:621-652. https://doi.org/10.1130/00167606(1954)65[621:SOTOLD]2.0.CO;2 
Pohle, A. and Klug, C. 2018. Body size of orthoconic cephalopods from the late Silurian and Devonian of the Anti?Atlas (Morocco), Lethaia, 51:126-148. https://doi.org/10.1111/let.12234

Rakociński, M. and E. Borcuch. 2016. Concentrations of silicified cephalopods within upper Frasnian carbonate concretions from the Holy Cross Mountains, Poland. Palaeogeography, Palaeoclimatology, Palaeoecology, 449:475-483. https://doi.org/10.1016/ j.palaeo.2016.02.040

Rayburn, J., De Simone, D., Staley, A., Mahan, S., and Byron, S. 2015. Age of an ice dammed lake on the lee side of the Catskill Mountains, New York, and rough estimates for the rate of ice advance to the last glacial maximum, Geologic Society of America Abstracts with Programs, 47:713.

Soja, C., Gobetz, K., Thibeau, J., Zavala, E., and White, B. 1996. Taphonomy and paleobiological implications of Middle Devonian (Eifelian) nautiloid concentrates, Alaska. Palaios, 11:422-436. https://doi.org/10.2307/3515210

Sweet, W. 1964. Cephalopoda - general features. p. K4-K13. In Teichert, C., Kummel, B., Sweet, W.C., Stenzel, H.B., Furnish, W.M., Glenister, B.F., Erben, H.K., Moore, R.C., and Nodine Zeller, D.E. (eds), Treatise on Invertebrate Paleontology, Part K, Mollusca 3. Geological Society of America and University of Kansas Press, Boulder, Colorado, and Lawrence, Kansas.

Ver Straeten, C. 1995. Stratigraphic synthesis and tectonic and sequence stratigraphic framework, upper Lower and Middle Devonian, northern and central Appalachian Basin. Unpublished PhD Thesis, University of Rochester, Rochester, New York.

Ver Straeten, C. 2007. Basinwide stratigraphic synthesis and sequence stratigraphy, upper Pragian, Emsian and Eifelian stages (Lower to Middle Devonian), Appalachian Basin. Geological Society London, Special Publications, 278:39-81. https://doi.org/10.1144/SP278.3

Ver Straeten, C. 2009. The classic Devonian of the Catskill Front: a foreland basin record of Acadian Orogenesis, p. 7-1-7.54. In Vollmer, F., (ed.), New York State Geological Association Field Trip Guidebook 81st Annual Meeting.

Ver Straeten, C. 2010. Lessons from the foreland basin: Northern Appalachian basin perspectives on the Acadian orogeny. From Rodinia to Pangea: The lithotectonic record of the Appalachian Region. Geological Society of America Memoir, 206:251-282. https://doi.org/ 10.1130/2010.1206(12)

Ver Straeten, C. and Brett, C. 2000. Bulge migration and pinnacle reef development, Devonian Appalachian foreland basin. The Journal of Geology, 108:339-352. https://doi.org/10.1086/ 314402

Wani, R. 2007. How to recognize in situ fossil cephalopods: evidence from experiments with modern Nautilus. Lethaia, 40:305-311. https://doi.org/10.1111/j.1502-3931.2007.00029.x

Wendt, J. 1995. Shell directions as a tool in palaeocurrent analysis. Sedimentary Geology, 95:161-186. https://doi.org/10.1016/0037-0738(94)00104-3

Williams, L. 1980. Community succession in a Devonian patch reef (Onondaga Formation, New York)_Physical and Biotic Controls. Journal of Sedimentary Research, 50:1169-1185. https:/ /doi.org/10.1306/212F7BA3-2B24-11D7-8648000102C1865D 